Border Crossing 
This book is dedicated to our children:

Elliott, Jacob, and Leopold Burry

\&

Ruth Beatrice "Ruby" White 


\section{Border Crossing}

Russian Literature into Film

Edited by Alexander Burry and Frederick H. White 
Edinburgh University Press is one of the leading university presses in the UK. We publish academic books and journals in our selected subject areas across the humanities and social sciences, combining cuttingedge scholarship with high editorial and production values to produce academic works of lasting importance. For more information visit our website: www.edinburghuniversitypress.com

(C) editorial matter and organization Alexander Burry and Frederick H. White, 2016

(C) the chapters their several authors, 2016

Edinburgh University Press Ltd

The Tun-Holyrood Road

I 2 (2f) Jackson's Entry

Edinburgh EH8 8PJ

Typeset in I I I zpt Ehrhardt MT Pro by

Servis Filmsetting Ltd, Stockport, Cheshire, and printed and bound in Great Britain by CPI Group (UK) Ltd, Croydon CRo 4 YY

A CIP record for this book is available from the British Library

ISBN 978 I 4744 I I 424 (hardback)

ISBN 978 I 4744 I I 43 I (webready PDF)

ISBN 978 I 4744 I I 448 (epub)

The right of the contributors to be identified as authors of this work has been asserted in accordance with the Copyright, Designs and Patents Act I988 and the Copyright and Related Rights Regulations 2003 (SI No. 2498)

\section{Acknowledgments}

Grateful acknowledgment is made to the following sources for permission to reproduce material previously published elsewhere. Every effort has been made to trace the copyright holders, but if any have been inadvertently overlooked, the publisher will be pleased to make the necessary arrangements at the first opportunity.

Alastair Renfrew's chapter in this volume is reproduced with the permission of the Modern Humanities Research Association. The original appeared in 2007 in Modern Language Reviem I02(1): г 57-76.

Yuri Leving's chapter in this collection is a variation on a Russian language version originally published in the Nem Literary Observer. This version can be found as "Ideologiia travmirovannogo glaza, ili kak ubit' Annu Kareninu nezhno.” Novoe literaturnoe obozrenie, I25(I) (20I4): 75-I02. 